\title{
SOUTHERN JOURNAL OF
}

\author{
AGRICULTURAL \\ ECONOMICS
}

$\sin$

\author{
Volume 12, Number 1 \\ July, 1980
}

Published by

Southern Agricultural Economics Association 


\title{
SOUTHERN JOURNAL OF \\ AGRICULTURAL ECONOMICS
}

\author{
Volume 12, Number 1 \\ July, 1980
}

Copyright $\odot 1980$ by the Southern Agricultural Economics Association

\section{EDITORIAL COUNCIL}

\section{ROBERT N. SHULSTAD, University of Arkansas, Editor}

RALPH D. MAY, University of Arkansas, Associate Editor

JOHN L. ADRIAN, Auburn University

W. LANNY BATEMAN, Mississippi State University

STEVEN T. BUCCOLA, Virginia Polytechnic Institute and State University

DALE H. CARLEY, Georgia Experiment Station

DAVID E. ERVIN, University of Missouri-Columbia

LINDA K. LEE, Oklahoma State University

DANIEL L. McLEMORE, University of Tennessee

LYNN W. ROBBINS, University of Kentucky

RICHARD SHUMWAY, Texas A\&M University

RONALD WARD, University of Florida

GARY J. WELLS, Clemson University

WILLARD F. WILLIAMS, Texas Tech University

\section{EDITORIAL POLICY}

The purpose of the JOURNAL is to provide a forum for creative and scholarly work in Agricultural Economics and related areas. Contributions on methodology and applications in business, extension, research and teaching phases of Agricultural Economics are encouraged. Preference will be given to articles addressing problems and issues of concern in the southern region of the United States. Only articles recommended by the Editorial Council are accepted for publication.

The Editorial Council encourages constructive criticism of JOURNAL articles and will publish accepted comments and replies.

\section{EXECUTIVE COMMITTEE}

PRESIDENT. ........................... Garnett Bradford, University of Kentucky

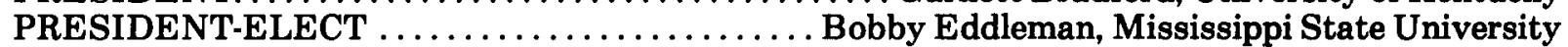
FIRST VICE-PRESIDENT. . . . . . . . . . . . . . . . . . Joe Havlicek, Virginia Polytechnic Institute and State University SECOND VICE-PRESIDENT ................... Neil R. Martin, Auburn University SECRETARY-TREASURER. . . . . . . E.......... Evan Drummond, University of Florida

Southern Journal of Agricultural Economics is published in July and December by the Southern Agricultural Economics Association.

Membership in the SAEA, consisting of persons and organizations having a professional interest in agricultural economics, includes subscription to the journal. Regular membership dues are $\$ 10.00$. Junior membership dues are $\$ 5.00$.

The annual subscription rate for libraries and other institutions is $\$ 15.00$. Single copies of current issues are available to individuals at a price of $\$ 5.00$.

Please address all subscription, membership and change of address requests to $H$. Evan Drummond, Food and Resource Economics Department, McCarty Hall, University of Florida, Gainesville, Florida 32611. 


\section{SOUTHERN JOURNAL OF}

\section{AGRICULTURAL ECONOMICS}

\section{Volume 12, Number 1}

July, 1980

\section{Published by}

Southern Agricultural Economics Association 


\section{PAST OFFICERS, SAEA}

\begin{tabular}{|c|c|c|c|}
\hline Year & President & President-Elect & Vice-President \\
\hline $1968-69$ & $\begin{array}{l}\text { Robert W. Rudd } \\
\text { Univ. of Kentucky }\end{array}$ & $\begin{array}{l}\text { Marshall R. Godwin } \\
\text { Texas A\&M Univ. }\end{array}$ & $\begin{array}{l}\text { A. D. Seale, Jr. } \\
\text { Miss. State Univ. }\end{array}$ \\
\hline 1969-70 & $\begin{array}{l}\text { Marshall R. Godwin } \\
\text { Texas A\&M Univ. }\end{array}$ & $\begin{array}{l}\text { T. J. Whatley } \\
\text { Univ. of Tennessee }\end{array}$ & $\begin{array}{l}\text { W. J. Lanham } \\
\text { Clemson Univ. }\end{array}$ \\
\hline $1970-71$ & $\begin{array}{l}\text { T. J. Whatley } \\
\text { Univ. of Tennessee }\end{array}$ & $\begin{array}{l}\text { Kenneth R. Tefertiller } \\
\text { Univ. of Florida }\end{array}$ & $\begin{array}{l}\text { Willard F. Williams } \\
\text { Texas Tech. Univ. }\end{array}$ \\
\hline $1971-72$ & $\begin{array}{l}\text { Kenneth R. Tefertiller } \\
\text { Univ. of Florida }\end{array}$ & $\begin{array}{l}\text { James S. Plaxico } \\
\text { Okla. State Univ. }\end{array}$ & $\begin{array}{l}\text { William E. Black } \\
\text { Texas A\&M Univ. }\end{array}$ \\
\hline $1972-73$ & $\begin{array}{l}\text { James S. Plaxico } \\
\text { Okla. State Univ. }\end{array}$ & $\begin{array}{l}\text { Verner G. Hurt } \\
\text { Miss. State Univ. }\end{array}$ & $\begin{array}{l}\text { Charles D. Covey } \\
\text { Univ. of Florida }\end{array}$ \\
\hline $1973-74$ & $\begin{array}{l}\text { Verner G. Hurt } \\
\text { Miss. State Univ. }\end{array}$ & $\begin{array}{l}\text { Joseph D. Purcell } \\
\text { U. of Georgia (Exper.) }\end{array}$ & $\begin{array}{l}\text { James B. Bell } \\
\text { Virginia (VPI \& SU) }\end{array}$ \\
\hline $1974-75$ & $\begin{array}{l}\text { Joseph C. Purcell } \\
\text { U. of Georgia (Exper.) }\end{array}$ & $\begin{array}{l}\text { Henry J. Meenen } \\
\text { Univ. of Arkansas }\end{array}$ & $\begin{array}{l}\text { Ted R. Nelson } \\
\text { Okla. State Univ. }\end{array}$ \\
\hline $1975-76$ & $\begin{array}{l}\text { Henry J. Meenen } \\
\text { Univ. of Arkansas }\end{array}$ & $\begin{array}{l}\text { Richard A. King } \\
\text { N. Carolina St. Univ. }\end{array}$ & \\
\hline $1976-77$ & $\begin{array}{l}\text { Richard A. King } \\
\text { N. Carolina St. Univ. }\end{array}$ & $\begin{array}{l}\text { Donald E. Farris } \\
\text { Texas A\&M Univ. }\end{array}$ & \\
\hline $1977-78$ & $\begin{array}{l}\text { Donald E. Farris } \\
\text { Texas A\&M Univ. }\end{array}$ & $\begin{array}{l}\text { Joe Coffey } \\
\text { Virginia (VPI \& SU) }\end{array}$ & \\
\hline 1978.79 & $\begin{array}{l}\text { Joe Coffey } \\
\text { Virginia (VPI \& SU) }\end{array}$ & $\begin{array}{l}\text { Leo Blakley } \\
\text { Okla. State Univ. }\end{array}$ & \\
\hline $1979-80$ & $\begin{array}{l}\text { Leo Blakley } \\
\text { Okla. State Univ. }\end{array}$ & $\begin{array}{l}\text { Garnett Bradford } \\
\text { Univ. of Kentucky }\end{array}$ & \\
\hline $1980-81$ & $\begin{array}{l}\text { Garnett Bradford } \\
\text { Univ. of Kentucky }\end{array}$ & $\begin{array}{l}\text { Bobby Eddleman } \\
\text { Miss. State Univ. }\end{array}$ & \\
\hline
\end{tabular}

Vernon R. Eidman
Okla. State Univ.
Garnett Bradford
Univ. of Kentucky
Calvin R. Berry
Univ. of Arkansas
Bobby Eddleman
Miss. State Univ.
John Lee
USDA, Washington, DC
Joe Havlicek
Virginia (VPI \& SU)

First Vice-President

Second Vice-Pres.

James L. Pearson

USDA, Washington, DC

Thomas G. Brown

Univ. of Missouri

Robert Raunikar

U. of Georgia (Exper.)

Hal Harris

Clemson Univ.

John Holt

Univ. of Florida

Neil R. Martin

Auburn Univ.

\section{Secretary-Treasurer}

John C. Redman Univ. of Kentucky

Luther H. Keller

Univ. of Tennessee

Luther H. Keller

Univ. of Tennessee

Luther H. Keller

Univ. of Tennessee

Luther H. Keller

Univ. of Tennessee

James H. Simpson

Miss. State Univ.

James H. Simpson

Miss. State Univ.

James H. Simpson

Miss. State Univ.

James H. Simpson

Miss. State Univ.

Gene A. Mathia N. Carolina St. Univ.

Gene A. Mathia N. Carolina St. Univ.

Gene A. Mathia

Texas Tech Univ.

H. Evan Drummond

Univ. of Florida 


\section{CONTENTS}

A Framework for Food and Agricultural

Policy in the 1980s

John E. Lee, Jr.

Issues Involved in Formulating a Structures

Policy for U.S. Agriculture

Neal Walker

Commodity Policy Issues for the 1980s

Milton H. Ericksen and James D. Johnson ........................ 17

A Critique of Federal Agricultural Programs

E. C. Pasour, Jr.

The Future of Federal Programs for

Southern Commodities

John W. Goodwin, Howard C. Williams,

Joseph A. Ware and Robert L. Stansberry

Energy Problems and Alternatives:

Implications for the South

David L. Debertin, Angelos Pagoulatos.

Comments on Energy Problems and Alternatives:

Implications for the South

James C. Hite

Food and Agriculture in the 1980s: The

Implied Research Priorities

B. R. Eddleman and Joseph C. Purcell

The Role of Market Price-Weight Relationships

in Optimal Beef Cattle Backgrounding Programs

Steven T. Buccola, Ernest Bentley, Warren B. Jessee

Lead-Lag Relationships Between Pork Prices

at the Retail, Wholesale, and Farm Levels

Steven E. Miller.

Implementation of Electronic Marketing of Slaughter

Cattle in Virginia: Requirements and Procedures

James A. Russell and Wayne D. Purcell.

The Impact of Selected Hedging Strategies on the

Cash Flow Position of Cattle Feeders

Wayne D. Purcell and Don A. Fiffe .

Toward a Performance of Evaluation of the Carcass

Beef Market-Weak Form Test of the Efficient Market's Model

Clement E. Ward 
Optimum Number and Location of Manufacturing

Milk Plants to Minimize Marketing Costs

Robert L. Beck and J. Don Goodin

Forecasting South Carolina Tomato Prices

Prior to Planting

Gary J. Wells

A Model of Weekly Price Discovery for Florida Celery

J. Scott Shonkwiler and Emilio Pagoulatos

U.S. Aggregate Agricultural Production Elasticities

Estimated by an ARIMA Factor Share Adjustment Model

C. Richard Shumway and Hovav Talpaz

Small Farm Polyperiod Planning Model for

Developing Economies

John R. Allison and James E. Epperson. ............................ 127

Application of a Bio-Economic-Engineering Model

for Shrimp Mariculture Systems

Charles M. Adams, Wade L. Griffin,

John P. Nichols and Robert E. Brick.

Developing Regional Input-Output Models from the U.N.

Format Adopted by the U.S. in the New 1972 Input-Output Model

Dennis DiPietre, Rodney L. Walker and David R. Martella

Some Evidence on Pecuniary Economies of Size for Farm Firms

Benard V. Tew, Stan Spurlock,

Wesley N. Musser and Bill R. Miller

The Profitability of Agricultural Customers for

Commercial Banks in the Southeast

William E. Hardy, Jr. and Michael W. Moore.

Objective Evaluation for Agricultural Lending

William E. Hardy, Jr. and Johno B. Weed

A Control Theory Approach to Optimal Irrigation

Scheduling in the Oklahoma Panhandle

Thomas R. Harris and Harry P. Mapp, Jr.

Implementation of New Conservation Programs and the

Need to Respond to Changing Market Conditions

Clayton W. Ogg and Ralph E. Heimlich.

Inland/Ocean Waterborne Transportation Innovations

and Port Charges

Gary L. Belcher, James R. Jones and Karl H. Lindeborg. . . . . . . . . . . . . . . 179

Energy Accounting: The Case of Farm Machinery in Maryland

Phillips Foster, John Flemming and Dennis Wichelns .................... 189

The Impact of New Industry on County Government

Property Tax Revenue

Mark Henry and Kathy Lambert.

Measurement and Modeling of Farmers' Goals:

An Evaluation and Suggestions

George F. Patrick and Brian F. Blake. 